\title{
Element storage in spores of Gigaspora margarita Becker \& Hall measured by electron energy loss spectroscopy (EELS)
}

\author{
Andre Freire Cruz ${ }^{1,2}$
}

Received: Juny 10, 2003. Accepted: Dezember 03, 2003

\begin{abstract}
RESUMO - (Elementos de armazenamento em esporos de Gigaspora margarita Becker \& Hall medidos por espectroscopia com perda de energia em elétrons (EEES)). As estruturas de armazenamento em esporos de Gigaspora margarita Becker \& Hall, um fungo micorrízico arbuscular, foram analisadas por microscópio eletrônico de transmissão (MET) e espectroscopia com perda de energia em elétrons (EEES). Os esporos foram hidratados, criofixados por pressão em baixa temperatura e submetidos a substituição em congelamento, embebidos e preparados para observações no MET. As técnicas de criofixação revelaram que as estruturas de armazenamento nos esporos são compostas de lipídios, grânulos elétron densos (GED), corpos protéicos e partículas de glicogênio. Por EEES foi detectada a presença de nitrogênio $(\mathrm{N})$ e carbono $(\mathrm{C})$ nestas estruturas de armazenamento e em organismos similares a bactérias (OSB). Uma pequena quantia de $\mathrm{P}$ foi detectada nos vacúolos e nos OSB. O exame por MET e EEES indicaram a presença de estruturas de armazenamento nos esporos e alguns elementos essenciais $(\mathrm{N}, \mathrm{P}$ e $\mathrm{C})$ nessas.
\end{abstract}

Palavras-chave: fungo micorrízico arbuscular, EELS, armazenamento, microscópio eletrônico de transmissão

\begin{abstract}
Element storage in spores of Gigaspora margarita Becker \& Hall measured by electron energy loss spectroscopy (EELS)). The storage structures of spores of Gigaspora margarita Becker \& Hall, an arbuscular mycorrhizal fungus, were analyzed by a transmission electronic microscope (TEM) and electron energy loss spectroscopy (EELS). The spores were hydrated, cryofixed using high pressure freezing, submitted to freeze substitution, embedded and prepared for TEM observations. The cryotechniques revealed that the storage structures in the spores are composed of lipids, electron dense granules (EDG), protein bodies and glycogen particles. The EELS detected the presence of nitrogen $(\mathrm{N})$ and carbon $(\mathrm{C})$ in these storage structures and in Bacteria-like organisms (BLO). Some amount of $\mathrm{P}$ was detected in the vacuoles and in BLO. The TEM and EELS techniques indicate the presence of storage structures in the fungal spore, and some essential elements (N, P and $\mathrm{C})$ in these structures.
\end{abstract}

Key words: arbuscular mycorrhizal fungi, EELS, storage, transmission electronic microscope

\section{Introduction}

Arbuscular mycorrhizal fungi (AMF) live in a symbiotic association with many land plants, and in most cases significantly change host physiology and function in support of plant growth in a variety of ways, such as the improvement of plant nutrition and increase of tolerance to environmental stress (Elliott \& Coleman 1988). In addition to the intraradical structures (vesicles and arbuscules), these symbionts produces spores, which develop outside the host plant and are essential for the survival of the species and to complete the fungal life cycle.

In temperate zones, the storage pools in ectomycorrhizae are important factors for plant survival, especially during periods of low nitrogen and low photosynthetic activity (Turnau et al. 2001).
Usually the carbon skeletons of the fungi are needed for the synthesis of glycogen, amino acids and proteins, which are temporarily stored in the mycorrhizae. AM symbioses are also potentially important as a sink of plant carbon in order to alleviate the photosynthetic down-regulation (Fitter et al. 2000) and $\mathrm{N}$ deposition (Treseder \& Allen 2000). The $\mathrm{C}$ and $\mathrm{N}$ stored in glomalin, a glycoprotein produced by AMF concentrated in soil (Wright \& Upadhyaya 1998), can make a significant contribution to soil carbon and nitrogen pools, as the amount of these elements in AMF represents around 5\% of total soil C and N (Rillig et al. 2001).

The morphology and storage structures of spores are fundamental for AMF studies (Bonfante et al. 1994), since we can understand the mechanisms of spore survival in the absence of host plants. According to these authors, lipids, protein-like bodies and glycogen

\footnotetext{
1 Eberhard-Karls-Universität Tübingen, Botanisches Institute/Spezielle Mikologie, Germany

2 Corresponding Author: Dept. of Soil Science, Univ. of Saskatchewan 51 Campus Drive, Saskatoon, SK, 57 N, 5 AB Canadá (andre.fcruz@usask.ca)
} 
have been identified as storage structures in Gigaspora margarita spores. They suggested that comparing with the events in plant cells, the secretion and storage of elements might happen in spores during some metabolic processes, such as mitosis and growth of the germination mycelium. The main difficulty for direct observations is the complexity and thickness of AMF spore cell walls rich in hydrophobic substances, which create a barrier to the fixative (Bonfante \& Vian 1994).

The identification of sites of element localization in the organelles at cellular level would contribute to clarify the process involved in their deposition in the spores. The technique of electron energy loss spectroscopy (EELS), generally used in association with transmission electronic microscopy (TEM), permits the localization and identification of all elements at a resolution usually unattainable (Kottke 1991). However, the need to embed the material might cause a risk to lose substances and cells with damaged membranes are more susceptible to be reached. Kottke et al. (1995) demonstrated the sequestration of $\mathrm{N}$ and $\mathrm{P}$ in osmophilic bodies in the hyphal mantle of Cenococum geophilum Fr. mycorrhizas as detected by EELS. This technique detected $\mathrm{P}$ and $\mathrm{N}$ in vacuolar bodies of Xerocomus badius - Picea abies mycorrhizas (Kottke et al. 1998) and precisely located the position of these elements in the small osmophilic bodies of the mycelium of Laccaria amethystea (Kottke \& Martin 1994).

Translocations of storage compounds in mycorrhizal fungi determined by the nuclear magnetic resonance method have also been reported (Bago et al. 1999; Pfeffer et al. 2001). Bucking et al. (1998) evaluated the elemental composition of vacuolar granules in different ectomycorrhizal fungi by EELS and energy dispersive X-ray spectroscopy (EDXS). These authors found that respective to the analysis of elemental composition in the cell organs and the different preparation techniques, the EELS method has advantages and limits. In their experiment it could not detect some cations in polyphosphate granules, which are strong negative polyanions. As EELS has detected elemental deposition in ectomycorrhizae, this technique may be useful for AMF spores, conditional to an efficient preparation method. In this study, the internal storage structures and the elemental $(\mathrm{N}, \mathrm{P}$ and $\mathrm{C})$ composition of $G$. margarita spores by using the electron energy loss spectroscopy (EELS) were investigated. The main objective was to determine the localization of N, C and P in the storage structures of the spores.

\section{Materials and methods}

Fungal material and microscopic analyses - Around 20 spores of $G$. margarita, obtained from a commercial inoculum (Biorize Ltd. - France), were surface-sterilized for $15 \mathrm{~min}$ in 5\% chloramine T plus $0.04 \%$ streptomycin on a clean bench, and rinsed with distilled and sterilized water for 7 times under aseptic conditions. They were kept for 15 days in distilled water ( $\mathrm{pH}$ 6.5) in Petri dishes (10 spores per Petri dish) at $25^{\circ} \mathrm{C}$ in the dark for hydration, and later submitted to cryofixation.

The cryofixation and freeze substitution followed the procedures of Bonfante et al. (1994). The spores were vacuum-infiltrated in buffer solution and the samples were placed in an aluminium holder and immediately frozen at high pressure Balzer. The frozen samples were stored in liquid nitrogen until the start of freeze substitution. The samples were freeze substituted in $4 \%$ osmium tetroxide from $-90^{\circ} \mathrm{C}$ to $0^{\circ} \mathrm{C}$ during 3 days, and then washed in dry acetone 3 times, while the temperature was rising $10^{\circ} \mathrm{C}$. After washing they were infiltrated with Vinil cyclohexen dioxid (ERL)/acetone mixture from $25 \%$ to $100 \%$ over 4 days at room temperature. Microscopic slides were sprayed with Teflon 3 times, and the samples placed in fresh ERL between two slides. These slides were placed in the oven at $70^{\circ} \mathrm{C}$ for 3 days. The embedded spores were fixed on top of ERL blocks by using a twocomponent-glue and again hardened in the oven for 1 day.

Sections of $75 \mu \mathrm{m}$ thickness were stained with crystal violet, which produces a light red color in the cytosol for general histological observations using light microscopy. Sections $(70 \mathrm{~nm})$ were transferred to Formvar (polyvinyl formal)-covered copper blends, stained with uranyl acetate and lead citrate, then studied by conventional transmission electron microscope (TEM902 Zeiss, 80kV). Glycogen was observed in sections subjected to the periodic acidthiocarbohydrazide-silver proteinate test (PATAg test) (Thiéry 1967; Lewis \& Knight 1977) for general visualization of polysaccharides. Sections about $100 \mathrm{~nm}$ thick on gold grids were dipped in periodic acid (1\%) for $30 \mathrm{~min}$, washed 5 times in double distilled water and exposed to thiocarbohydrazide $(0.2 \%$ in $20 \%$ acetic acid) for $5 \mathrm{~h}$. Then samples were transferred to double distilled water and submitted to a passage through a diluted acetic acid series (20,15, 10, 5 and 2.5\% $5 \mathrm{~min}$ for each step). After washing three times in double distilled water, the sections were stained with 
silver proteinate (1\%) for $30 \mathrm{~min}$ in the dark, washed 3 times and dried.

Another specific staining for sulfur-rich proteins (-SH-groups) was carried out with the $100 \mathrm{~nm}$ sections (Lewis \& Knight 1977). The solutions were prepared as follows: Solution A- $5 \mathrm{ml}$ of $5 \%$ silver nitrate with $100 \mathrm{ml}$ of $3 \%$ hexamethylene tetramine; Solution B- $10 \mathrm{ml}$ of $1.44 \%$ boric acid with $100 \mathrm{ml}$ of $1.9 \%$ borax (Na-tetraborax). A mixture was prepared with $25 \mathrm{ml}$ of solution $\mathrm{A}, 5 \mathrm{ml}$ of B and 25 of double distilled water. The grids were floated for $90 \mathrm{~min}$ at $45^{\circ} \mathrm{C}$ in the dark, and then washed 3 times in double distilled water. The sections were submitted to contrast with uranyl acetate and lead citrate and the preparations were examined with TEM.

Electron energy loss spectroscopy (EELS) - The amounts of $\mathrm{N}, \mathrm{C}$ and $\mathrm{P}$ in the spores were measured on sections 40-50nm thick, without further treatment, by using the Electron Energy Loss Spectroscopy (EELS), connected to the TEM, according to the procedures described by Kottke (1991) and Kottke et al. (1995). The system was set as follows: Spectra were acquired at a magnification of 50,000. The peak area of the K edge (401.5 eV loss) for N, $132.2 \mathrm{eV}$ for $\mathrm{P}$ and $284 \mathrm{eV}$ for $\mathrm{C}$ were used to measure the amount of these elements (Fig. 1). They were calculated by using power law, strip and area calculation defined as follows. N: power law interpolation 360 to $389 \mathrm{eV}$, extrapolation 389 to 440 , strip 392 to $432 \mathrm{eV}$, area calculation 395 to $419 \mathrm{eV}$; C: power law interpolation 250 to $275 \mathrm{eV}$, extrapolation 275 to 340 , strip 260 to $320 \mathrm{eV}$, area calculation 280 to $310 \mathrm{eV}$; P: power law interpolation 105 to $125 \mathrm{eV}$, extrapolation
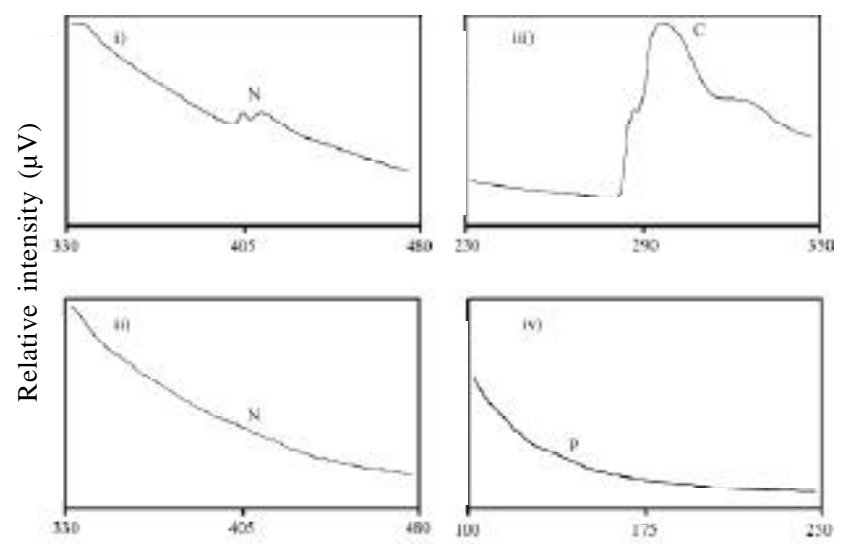

Figure 1. EELS measurements of the relative level of nitrogen $(\mathrm{N})$ in the electron-dense granules-EDG (i) and lipds (ii); carbon (C) in the lipids (iii); and phosphorus (P) in the vacuoles (iv). In the EDG (i) the amount of $\mathrm{N}$ is higher than in lipds (ii).
125 to 220 , strip 120 to $215 \mathrm{eV}$, area calculation 130 to $190 \mathrm{eV}$ (Fig. 2). The relative amount of each element (Fig. 2) was calculated by the following equation: 1000

Relative amount $=$ area calculation $/(\mathrm{A} 1+\mathrm{A} 2) \times$

A1 - Total energy income represented by the area of the power law interpolation

A2 - Total energy income represented by the area of extrapolation
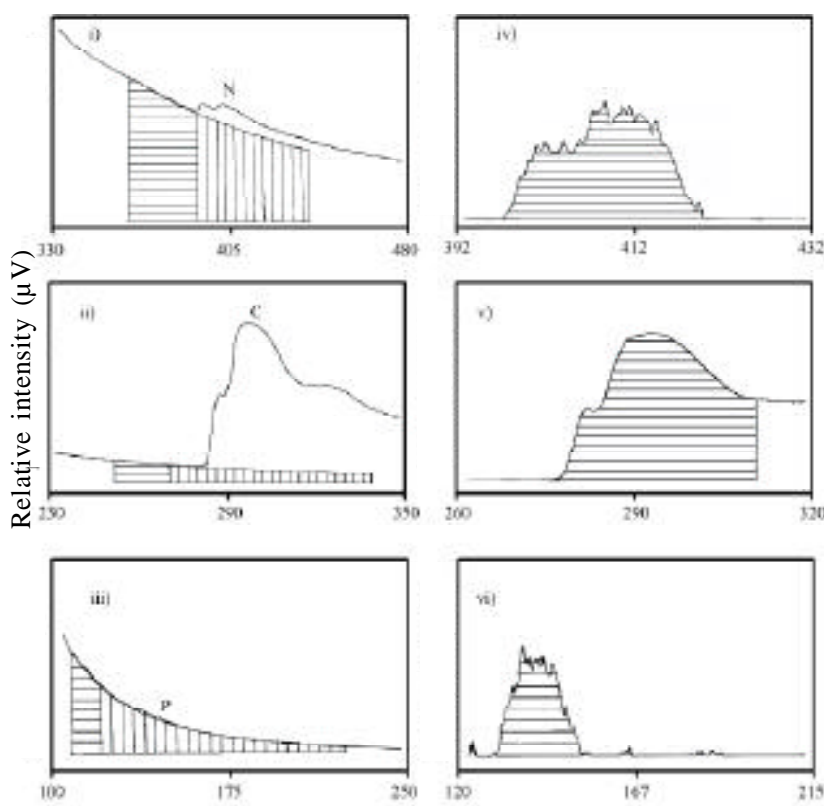

Figure 2. EELS-spectra of N (i, iv), C (ii, v), and P (iii, vi). A defined area before the element edge (horizontal hatched $\mathrm{i}, \mathrm{ii}$, iii) was used to extrapolate an area containing no element (vertical hatched area). The relative amount of N, C (Figures 14 and 15) and $\mathrm{P}$ (in the text-results) was calculated by the proportion between energy increment caused by the element (iv, $v, v i$ ) and the total energy income (both hatched areas in i, ii and iii). In the case of $\mathrm{C}$ the values were subtracted by those found in the embedding media. However, the absolute amount of the elemnts cannot be calculated once that standards for EELS are not available (Kottke et al. 1995).

In the case specific for $\mathrm{C}$ the results were subtracted from those found in the pure Epon. As mentioned by Kottke et al. (1995), the relative concentrations of the elements were influenced by the section thickness. The data were statistically analyzed and the standard deviation calculated by Excel program.

\section{Results}

Description of internal structures in spores - The spores had a thick laminated wall and cytoplasm was 
redistributed into storage areas containing many lipid droplets and vacuoles during the hydration (Fig. 3-5). In the spores where storage areas were predominant, lipids were found as big and regular black bodies limited by a membrane (Fig. 4, 5).

The vacuoles ranged in content and were granular or homogeneously dense, and sometimes appeared to be electron-transparent (Fig. 5). The bacteria-like organisms (BLO) were often located in the vacuoles (Fig. 6), isolated or in-groups. In the cytosol there were some vesicles that appeared to be electron densegranules (EDG) rich in nitrogen (Fig. 7). Some vacuoles were empty, while others displayed compact electrondense bodies embedded in a dense matrix. These organelles were morphologically similar to the protein bodies of the storage tissues in vascular plants (Fig. 7,8), and often presented a black core. The $\mathrm{SH}$-groups staining showed the vacuole with protein bodies (Fig. 8), and the PATAg test revealed the presence of huge glycogen bodies organized in rosettes (Fig. 9).

Relative amounts of nitrogen $(\mathrm{N})$, carbon $(\mathrm{C})$ and phosphorus (P) detected by the EELS - The EELS analysis of the spores revealed that N, P and C were present in many bodies. However, only trace amounts of $\mathrm{P}$ were present in some bodies. There was a high variability in the level of these elements $(\mathrm{cv}=30 \%$; Fig. 10,11). This was partly caused by differences in section thickness and background influence on the measurements.

Nitrogen was present in the BLO, protein bodies, EDG, cytosol and lipids (Fig. 10). Among these organelles, the protein bodies, which were often located in the vacuoles and EDG contained the highest amount of $\mathrm{N}$ as compared to the others.

Carbon was detected in all structures of the spore, where $\mathrm{N}$ was present. The amount of $\mathrm{C}$ did not significantly differ among the bodies, but comparing the protein bodies with the BLO, the former had a greater amount of $\mathrm{C}$ (Fig. 11). Phosphorus was present only in the vacuoles $(8.8 \pm 3.2 ; n=3)$ and in the BLO $(6.6 \pm 1.5 ; \mathrm{n}=3)$, without differences in the amount.

\section{Discussion}

This study shows the storage structures in spores of G. margarita. The utilization of high-pressure freezing for cryofixation and freeze substitution contributed for the observation of these structures. The storage structures in the hydrated or germinating spores can be identified as lipid droplets, protein bodies inside the vacuoles, and glycogen particles (Bonfante et al. 1994), organelles observed in the spores by using TEM. However, the present study demonstrates that the electron-dense granules also might be considered as storage structures, since they are rich in $\mathrm{N}$ as detected by EELS. The staining technique for sulfur-rich proteins proved that the black granules found in the vacuoles might be protein bodies, since the other structures would not be detected by this method. Turnau et al. (1993) reported that some electron-dense bodies, suspected to be protein bodies with low $\mathrm{P}$ content and a high $\mathrm{N}$ composition, were found in Paxillus involutus.

Lipids have been shown to correspond to oleosomes consisting of triglicerides and phospholipids and are often found in fungal spores, in seeds and pollen grains (Weete 1981). According to Bonfante et al. (1994) the morphological similarities between the plant protein bodies and those observed on G. margarita spores suggest that a pathway of protein secretion involving vacuoles is active in AMF. The vacuoles as reserve structures are very common in seed tissues, where protein bodies are found in the parenchyma cells of endosperm or in cotyledon cells. Some vacuoles contain BLO with a rod shape and thick wall. Similar microorganisms are also commonly associated with AMF (Schüßler et al. 1994). The BLO were often located in the vacuoles, as already reported by some authors (Bonfante et al. 1994; Scannerini \& Bonfante 1991). They mentioned that better membrane preservation or the presence of different bacterial populations living inside the spores might explain the location of the BLO. However, the BLO in AMF have also been located in the cytoplasm, i.e outside the vacuoles (Maia \& Kimbrough 1998).

Plant storage cells may be considered similar to the spores of G. margarita as both contain lipids and protein bodies; however the presence of glycogen is a feature unique to fungi. The glycogen becomes important in more advanced stages of germination, when a part of the reserves are mobilized, as also in rust fungi (Mendgen 1973). The electron-dense granules contain melanin in addition to other wall constituents, which produce an electron-dense layer that play a role in defense against soil microorganisms (Bonfante et al. 1994).

The EELS results showed the presence of $\mathrm{N}, \mathrm{P}$ and $\mathrm{C}$ in the storage structures of G. margarita spores. Carbon was highly detected in these bodies, since it is the main element in the organic compounds of the 

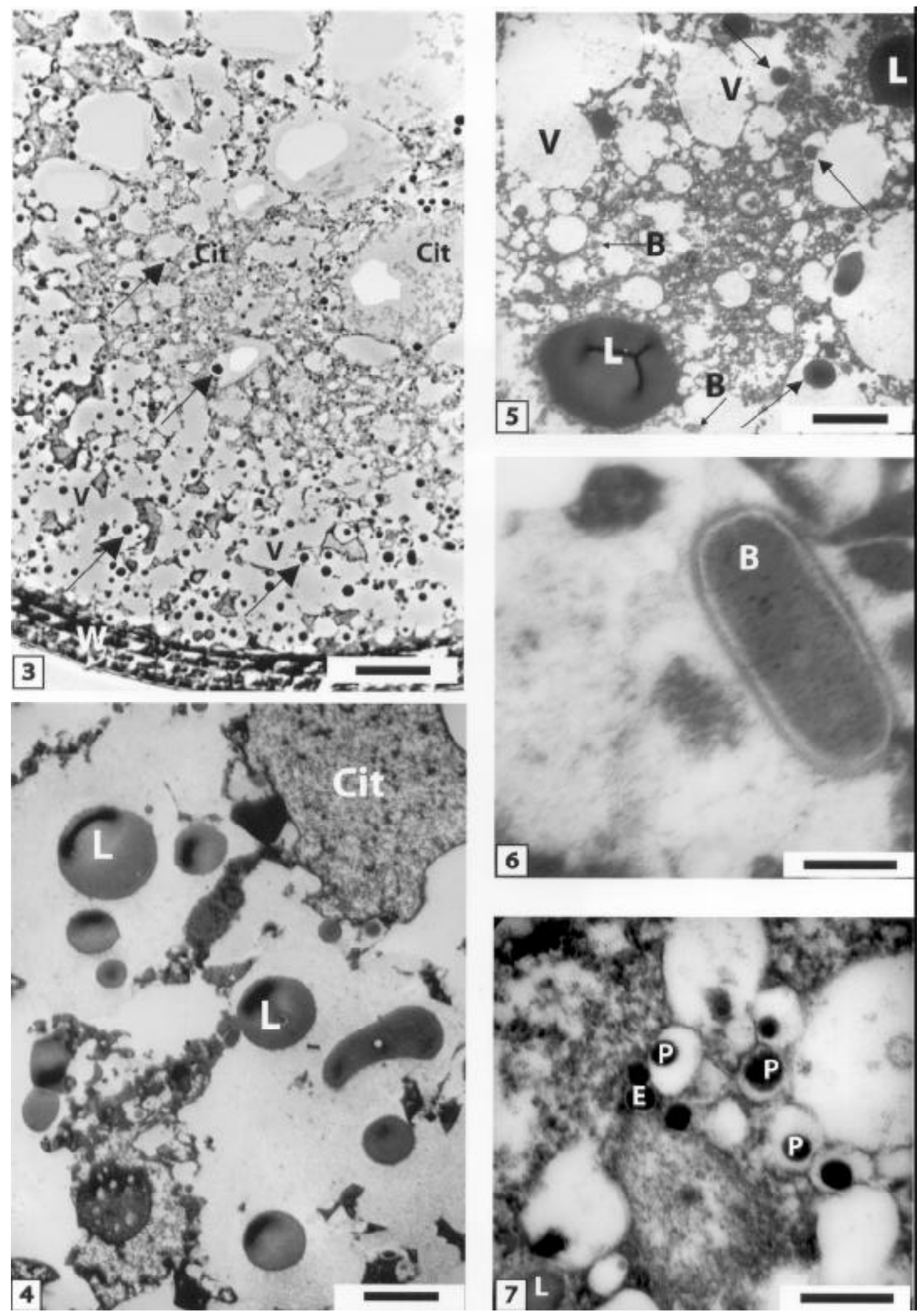

Figures 3-7. Internal structures of Gigaspora margarita Becker \& Hall spores. Figure 3. Light microscope section. The spore wall (W) is laminated, and the cytoplasm contain cytosol (Cit), vacuoles (V) with protein bodies (arrows). Bar $=20 \mu \mathrm{m}$. Figure 4 . TEM image showing lipds $(\mathrm{L})$ and a part of the cytosol (Cit). Bar $=2 \mu \mathrm{m}$. Figure 5. Ultrathin section showing some vacuoles, lipds $(\mathrm{L})$, protein bodies (arrows) and Bacteria-like organism (B). Bar $=3 \mu \mathrm{m}$. Figure 6. Ultrathin section showing Bacteria-like organism $(\mathrm{B}) . \mathrm{Bar}=0.2 \mu \mathrm{m}$. Figure 7. Electron dense granules (E) and lipds (L) are present in the cytosol, while some protein bodies (P) are often in the vacuoles. Bar $=0.2 \mu \mathrm{m}$. 

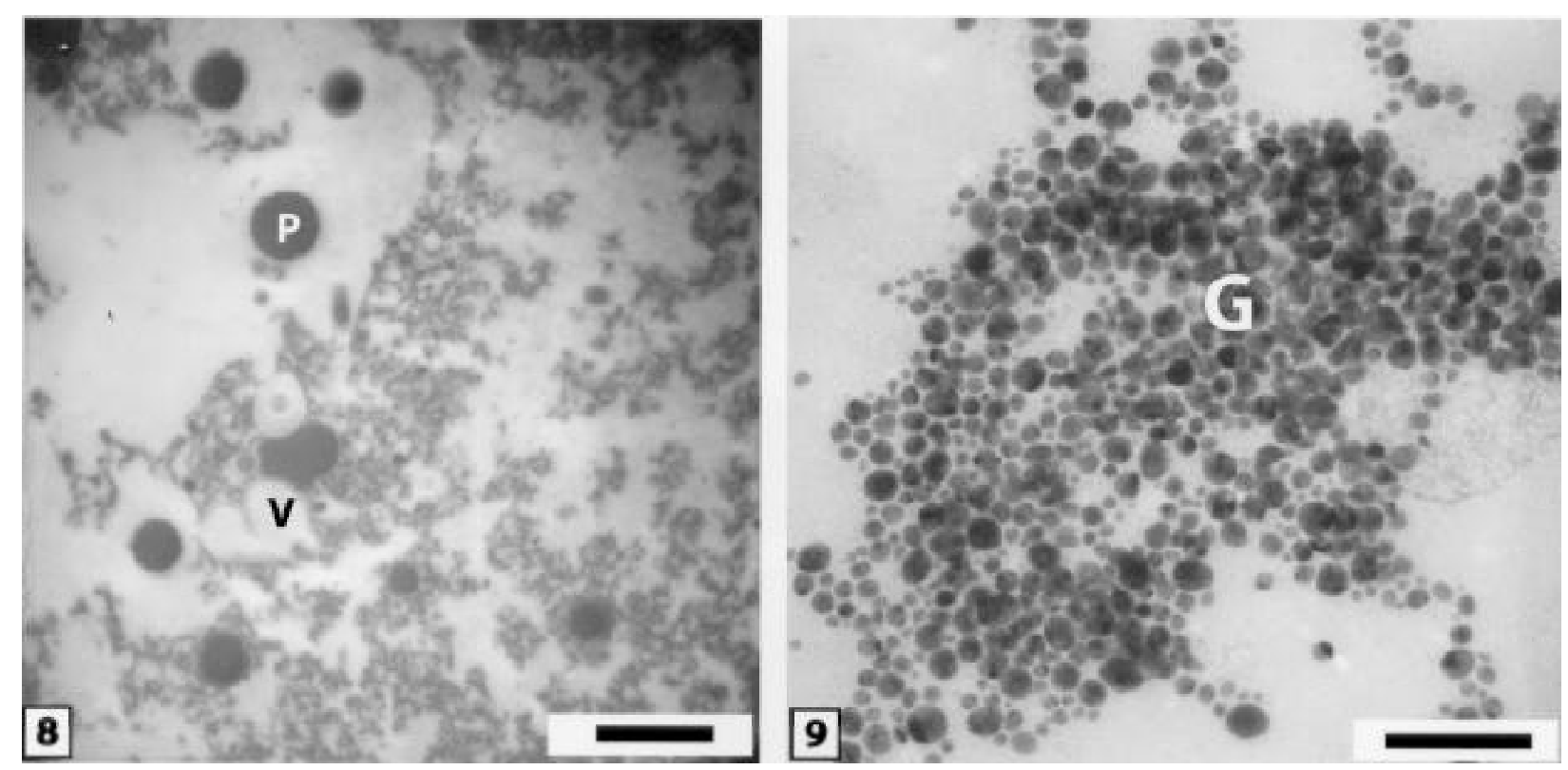

Figure 8. Internal structures of Gigaspora margarita Becker \& Hall spores - TEM electron micrograph after the sulphur-rich protein staining, showing the proteig bodies $(\mathrm{P})$ inside vacuoles $(\mathrm{V})$. Bar $=2 \mu \mathrm{m}$. Figure 9 . Aggregation of glycogen $(\mathrm{G})$ stained by the PATAg test. $\mathrm{Bar}=0.1 \mu \mathrm{m}$.

storage structures. In some of vacuoles and BLO P was also found, however in those bodies where $P$ was not detected, it is not possible to consider them devoid of it, because the detection limit of EELS in biological material is not yet clarified (Kottke et al. 1995). Some $\mathrm{N}$ and $\mathrm{P}$ loss might occur during the preparation of the material (Young et al. 1993). The localization of chemical elements in AMF spores by the EELS is important to clarify their structure, since it permits to characterize these organelles as a part of the storage components in the spores, and allows distinguishing these structures by their nutrient composition. By using the same method, N, P and heavy metal were found in ectomycorrhizas from polluted areas (Turnau et al. 1993). The storage capacity of the spores seems to be linked to the occurrence of bodies containing these

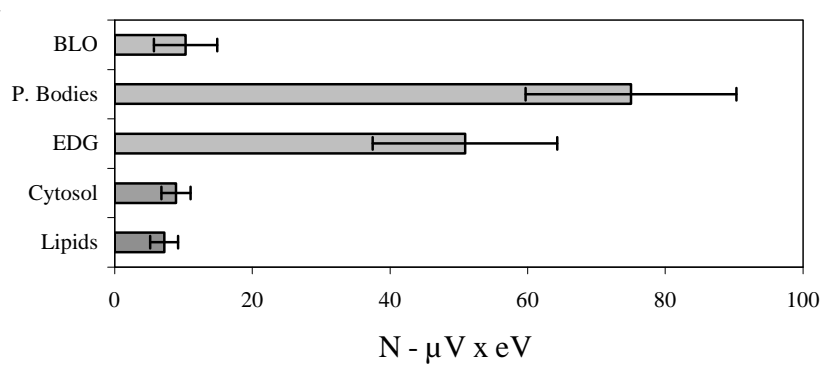

Figure 10 . EELS measurements of the relative amount of Nitrogen (N) in Gigaspora margarita Becker \& Hall spores. Horizontal bars indicate SD (six to 11 replications). elements, especially with regard to the presence of $\mathrm{N}$ and $\mathrm{P}$ in the vacuoles. The $\mathrm{N}$ storage in vacuolar bodies of rhizomorphs (Franz \& Acker 1995), and the accumulation of $\mathrm{N}$ and $\mathrm{P}$ in bodies connected to the cytoplasm (Young et al. 1993) were already reported.

Kottke et al. (1998) reported that in small osmophilic bodies, polyphosphates present in the vacuoles probably gave prominent $P$ peaks in EELS and in $\mathrm{N}$-containing vacuolar bodies $\mathrm{P}$ was also detected. They suggested that the detection of these elements explains why the storage ability of Xerocomus badius in plants of Picea abies and make this ectomycorrizal fungus functionally important on acidic soils, where nutrient availability is usually low. In our results, $\mathrm{N}$ was mostly detected in electron-dense granules and protein bodies while $\mathrm{P}$ was usually in the

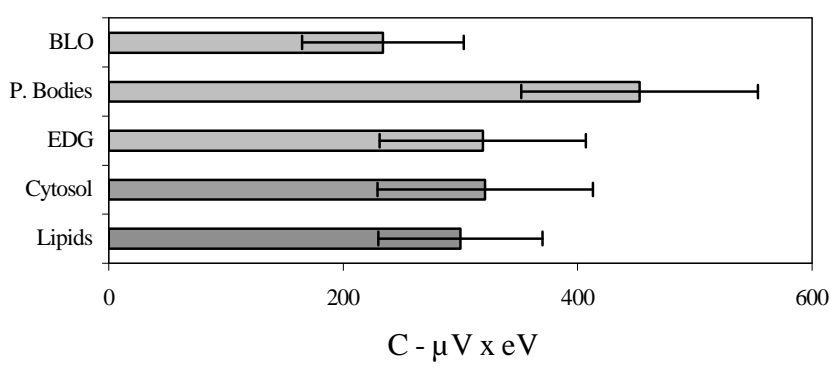

Figure 11. EELS measurements of the relative amount of Carbon (C) in Gigaspora margarita Becker \& Hall spores. Horizontal bars indicate SD (six to 11 replications). 
vacuoles. The accumulation of amino acids in the vacuolar bodies of $X$. badius bound to polyphosphate might justify these results (Kottke et al. 1998; Gerlitz \& Werk 1994), but further research is necessary to explain the location of $\mathrm{N}$ and $\mathrm{P}$ in the vacuoles of fungal spores.

These results suggest a link between storage structures in the AMF spores and the accumulation of nutritive elements (N, C and $\mathrm{P}$ ) as demonstrated by the EELS method. The localization of these elements in the organelles of the spores would help to explain their deposition in the spores, which is useful for spore survival. The spores of G. margarita contained storage structures basically composed by lipids, protein bodies and glycogen, which might be consumed for the host infection processes. The metabolism of AMF spores aims to produce energy, which supports mitosis and mycelium initial development (Bianciotto \& Bonfante 1993). Further researches using this technique could be done with spores from the natural environment to investigate presence of heavy metals in AMF spores.

\section{Acknowledgements}

This research was supported by the Alexander von Humboldt $(\mathrm{AvH})$ foundation, in Germany. Thanks to the Max Plank Institute, in Tübingen-Germany, for help with the cryofixation. Thanks to the staffs from Eberhard-Karls-Universität Tübingen, Botanisches Institute/Spezielle Mikologie for provide the facilities and advising about freeze substitution, TEM and EELS. Thanks also to Dr. C. Hamel and K. Hanson (Agriculture and Agri-Food Canada - Semiarid Prairie Agricultural Research Center), for the critical reviews on this paper.

\section{References}

Bago, B.; Pfeffer, P. E.; Douds, D. D.; Brouillette, J.; Bécard, G. \& Schachar-Hill, Y. 1999. Carbon metabolism in spores of the arbuscular mycorrhizal fungus Glomus intraradices as reveled by nuclear magnetic resonance spectroscopy. Plant Physiology 121: 263-271.

Bianciotto, V. \& Bonfante, P. 1993. Evidence of DNA replication in an arbuscular mycorrhizal fungus in the absence of the host plant. Protoplasma 176: 100-107.

Bonfante, P.; Balestrini, R. \& Mendgen, K. 1994. Storage and secretion processes in the spore of Gigaspora margarita Becker \& Hall as revealed by high-pressure freezing and freeze substitution. New Phytologist 128: 93-101.
Bonfante, P. \& Vian, B. 1994. Wall texture in the spore of a vesicular-arbuscular mycorrhizal fungus. Protoplasma 120: $51-60$.

Bucking, H.; Beckmann, S.; Heyser, W. \& Kottke, I. 1998. Elemental contents in vacuolar granules of ectomycorrhizal fungi measured by EELS and EDXS. A comparison of different methods and preparation techniques. Micron 29: 53-61.

Elliot, E.T. \& Coleman, D.C. 1988. Let the soil work for us. Ecological Bulletin 39: 23-32.

Fitter, A.H.; Heinemeyer, A. \& Staddon, P. L. 2000. The impact of elevated $\mathrm{CO}_{2}$ and global climate change on arbuscular mycorrhizas: a mycocentric approach. New Phytologist 147: 179-187.

Franz, F. \& Acker, G. 1995. Rhizomorphs of Picea abies ectomycorrhizas: ultrastructural aspects and elemental analysis (EELS and ESI) of hyphal inclusions. Nova Hedwigia Kryptogamenkd 60: 253-267.

Gerlitz, T.G. \& Werk, W.B. 1994. Investigations on phosphate uptake and polyphosphate metabolism by mycorrhized and non-mycorrhized roots of beech and pine as investigated by in vivo ${ }^{31} \mathrm{P}-\mathrm{NMR}$. Mycorrhiza 4: 207-214.

Kottke, I. 1991. Electron energy loss spectroscopy and imaging technique for subcellular localization of elements in mycorrhiza. In: Experiments with mycorrhizae. J.R. Norris \& D.J. Read (eds.). Methods in Microbiology 23: 369-382.

Kottke, I.; Holopainen, T.; Alanen, E. \& Turnau, K. 1995. Deposition of nitrogen in vacuolar bodies of Cenococum geophilum Fr. mycorrhizas as detected by electron energy loss spectroscopy. New Phytologist 129: 411-416.

Kottke, I. \& Martin, F. 1994. Demonstration of aluminum in polyphosphate of Laccaria amethystea (Bolt. Ex Hooker) Murr. by means of electron energy loss spectroscopy. Journal of Microscopy 174: 225-232.

Kottke, I.; Qian, X.M.; Pritsch; K., Haug, I. \& Oberwinkler, F. 1998. Xerocomus badius - Picea abies, an ectomycorrhiza of high activity and element storage capacity in acidic soil. Mycorrhiza 7: 267-275.

Lewis, P.R. \& Knight, D.P. 1977. Staining methods for sectioned material. North-Holland Publ. Company, Amsterdam, Netherlands.

Maia, L.C. \& Kimbrough, J.W. 1998. Ultrastructural studies of spores and hypha of a Glomus species. International Journal of Plant Science 159(4): 581-589.

Mendgen, K. 1973. Microbodies (glyoxysomes) in infection structures of Uromyces phaseoli. Protoplasma 78: 477-482.

Pfeffer, P.E.; Bago, B. \& Schachar-Hill, Y. 2001. Exploring mycorrhizal function with NMR spectroscopy. New Phytologist 150: 543-553.

Rillig, M.C.; Wright, S.F. \& Nichols, K.A.; Schmidt, W.F. \& Torn, M.S. 2001. Large contribution of arbuscular mycorrhizal fungi to soil carbon pools in tropical soils. Plant and Soil 233: 167-177.

Scannerini S. \& P. Bonfante. 1991. Bacteria and bacteria-like objects in endomycorrhizal fungi. Pp. 273-287. In: L. Margulis \& R. Fester (eds.). Symbiosis as a source of evolutionary innovation: speciation and morphogenesis. MIT Press, Cambridge. 
Schüßler, A.; Mollenhauer, D.; Schnepf, E. \& Kluge, M. 1994. Geosiphon pyriforme, an endosymbiotic association of fungus and cyanobacteria: the spore structure resembles that of arbuscular mycorrhizal (AM) fungi. Botanica Acta 107: $36-45$

Thiéry, J.P. 1967. Mise en évidence des polysaccharides sur coupes fines en microscopie électronique. Journal de Microscopie 6: 987-1018.

Turnau, K.; Kottke, I. \& Oberwinkler, F. 1993. Paxillus involutus - Pinus sylvestris mycorrhizae from heavily polluted forest. I. Element localization using electron energy loss spectroscopy and imaging. Botanica Acta 106: $213-219$.

Turnau, K.; Berger, A.; Loewe, A.; Einig, W.; Hampp, R.; Chalot, M.; Dizengremel, P. \& Kottke, I. 2001. Carbon dioxide concentration and nitrogen input affect the $\mathrm{C}$ and $\mathrm{N}$ storage pools in Amanita muscaria-Picea abies mycorrhizae. Tree Physiology 21: 93-99.
Treseder, K.K. \& Allen, M.F. 2000. Mycorrhizal fungi have a potential role in soil carbon storage under elevated $\mathrm{CO}_{2}$ and nitrogen deposition. New Phytologist 147: 189-200.

Weete, J.D. 1981. Lipids in fungal growth and reproduction. Pp. 463-485. In: G. Turian \& H.R. Hohl (eds.). The fungal spore: Morphogenetic controls. Academic Press.

Wright, S.F. \& Upadhyaya, A. 1998. A survey of soils for aggregate stability and glomalin, a glycoprotein produced by hyphae of arbuscular mycorrhizal fungi. Plant Soil 198: 97-107.

Young, N.; Bullock, S.; Orlovich, D.A. \& Ashford, A.E. 1993. Association of polyphosphate with protein in freezesubstituted sclerotia of Sclerotia minor. Protoplasma 174: $134-141$. 